\title{
Nexus between Ethnic Federalism and Creating National Identity Vis-À-Vis Nation Building in Contemporary Ethiopia
}

\author{
Desta Abebe; Ephrem Ahadu \\ Department of Civics and Ethical Studies, Wachemo University, Hosaena, Ethiopia
}

http://dx.doi.org/10.18415/ijmmu.v7i1.1327

\begin{abstract}
The current regime of Ethiopia (EPRDF) implemented ethnic federalism and reshaped the state along ethnic lines as soon as it assumes political power in 1991. As an exception to the general pattern in Africa the Ethiopian government, though not explicitly, encourages political parties to organize beside ethnic lines, and champions an ethicized federal state with a secession option, it is a worthy case study. This desk study, used secondary sources of data got from numerous literatures, aims to identify the nexus between ethnic federalism in creating national identity in relation with nation building. Although the Constitution embodies a doctrine of balance between unity and diversity to build one economic and political community by rectifying" past injustices", politicization of ethnicity under the context of ethnic federalism has encouraged ethnic cleavages by forming distinctiveness and differences which is a backlash against nation building and shared aspirations. Therefore, there is the need for visionary thinking outside the box of past injustices so that the antithesis for these injustices is not taken too far to the extent of derailing shared identity and shared aspirations. Ethnic Federalism may lead the country into neverending ethnic wars and eventually to disintegration. Thus, ethnic conflicts prevailing in Ethiopia may be caused by such technicality problems and the ethnic federal arrangement in Ethiopia needs an urgent reconsideration before the case moves to the worst scenario.
\end{abstract}

Keywords: Ethnic Federalism; Nation Building; National Identity; Nexus; Contemporary; Ethiopia

\section{Introduction}

In 1991, Ethiopia's new leaders established a multiethnic federation that provides for the right to secession. The secession clause was incorporated for reasons of ideology and necessity. The federation consists of largely ethnic-based territorial units and encourages political parties to organize along ethnic lines. The Ethiopian case is a radical change from most other federal systems. One of the ways Ethiopia's federalism varies from the other federal states, however, is in its allowance for the right of secession. The constitutional marrying of political pluralism and the right of secession makes Ethiopia's ethnic federalism unique. The overthrow of the military government by ethnic based liberation movements, Tigray Peoples Liberation Front (TPLF), has opened the new course for reorganizing the Ethiopia with the new ideology that is ethnic federalism. In 1991 Ethiopia accommodated ethnicity as a formal political element in the new 
state order. This makes the country relatively exceptional in Africa, where ethnic relations may be an obvious dynamic in national politics but not in any recognized form. Similarly Baweke (2015) indicated that federalism was introduced in Ethiopia in 1991 when the idea of selfdetermination for the nationalities ${ }^{\text {ee }}$, up to and including secession, was launched thereby devolving political, administrative and economic power to ethnically defined regional states.

Ethnicity, which was considered as tribalism has been treated as a valuable asset of ethnic groups and, therefore accorded high level of protection and recognition. Having taken ethnicity as emancipator, the creation of a new political system and administrative structures have been commenced on the foundations of ethnic autonomy and ethnic equality that assured a right for every ethnic group to have its own administrative unit as well as a right to develop and promote its own identity and language. Markakis notes that "overnight ethnicity became a legitimate and preferred principle of political organization, and provided the foundation for a reconstructed Ethiopian state" (Baweke, 2015). Opponents of ethnic federalism panic that it calls ethnic conflict and risks state breakup hence the Ethiopian state, may face the same fate as the USSR.

National representation and power sharing are key structural issues in state-society relations. The debate is centered on what kind of representation modalities and power-sharing formula the country should adopt. Some scholars and politicians advocate individual-based representation that echoes the liberal principle of citizenship. Others argue for ethnicity-based federation as a viable means of accommodating competing interests of diverse ethnic and linguistic groups(Bekele, Kjosavik, \& Shanmugaratnam, 2016) it is essential to ask how the Ethiopian ethnic federalism model could keep the integrity of Nations, Nationalities and Peoples (here after NNPs) and its promising role for development. Stated differently, it is essential to examine whether the Ethiopian Ethnic Federalism allows ethnic groups to build a common sense of purpose, a sense of shared destiny and collective imagination of belongingness while at the same time structuring inclusive institutions for development (Baweke, 2015). The chief challenge was to replace ethnic identity with national identity, rather than simply superimpose the latter. Suspicion of ethnic nationalism is discernible to this day. In Uganda, to take an extreme example, the state altogether disallows ethnic parties; it champions a de-ethicized unitary state. (Temesgen, 2015a) unlike Uganda, Ethiopian ethnic federalism inspires political parties to establish along ethnic lines, and champions an ethnicized federal state. As an exception to the general shape in Africa, it is worthy of a close examination.

Supporters of ethnic federalism point out that it has maintained the unity of the Ethiopian peoples and the territorial integrity of the state, while providing full recognition to the principle of ethnic equality. It is important to examine objectively whether ethnic federalism is a viable way of nation building and resolving conflict between ethno nationalism and state nationalism. Now that the ethnic federal experiment is more than a decade old, it is possible to make a tentative evaluation of its performance.

\section{The Post-1991 Dynamics: Political Transformation and Continuity}

The Tigray Peoples' Liberation Front (TPLF) took over in Addis Ababa in May 1991, after its victory in the armed struggle. As the ticket of the TPLF was ethno-nationalism, having its origins in an ideology to realize greater autonomy for the region of Tigray in a reformed Ethiopia it went on to institute an ethnic-based political system that came to be known as "ethnic 
federalism" and in name a republic.(Abbink, 2009). Scholars like (Bekele et al., 2016), present the post-1991 political dynamics in different chronological order. However, we identify the political order of the post-1991 period in three phases: regime transition, consolidation, and contestation. The first phase spans the years between 1991 and 1997, encompassing an attempt at political transition to a democratic system through reconstruction of the state and adopting the new constitutional order. Accordingly, three radical types of reforms were undertaken: decentralization of the state, democratization of politics and liberalization of the economy ((Habtu, 2003)). The new federal constitution that was established upon a structural foundation for post-1991 state-society relations was ratified in 1995 ((Abebe, 2012)). It sets out a new federal arrangement based on ethnic identity, bestows popular sovereignty on ethnic groups, and endows self-determination rights including "the right to secessions" to nationalities ((Gizachew, 2019), (Fessha, Y. T. and Van der Beken, 2013), (Beken, 2007), (Abbink, 2009)). Precisely it means that the Ethiopian government adopted that is Ethnic based federalism for the first time in the history of Ethiopia. The post-1991 political order is unique in the sense of restructuring the Ethiopian state along ethnic federalism and promoting cultural pluralism of competing ethnic groups. Both factions have negated the idea of pan-Ethiopianism (a unified and single Ethiopia) and uphold ethnic nationalism. (Bekele et al., 2016) since Ethnicity, has occupied the centre stage of national politics. Most of the political forces which were well-known in the aftermath of the 1974 revolution were ethnicity-orientated (Mengistu, 2015).

The rise of EPRDF to hegemonic status and the virtual weakening of opposition political forces prompted the beginning of the third phase (2005-present) in which the emergency of ethnic based federalism begins showing its fruit for instance religious institutions, particularly Islamic, emerged as contending forces against the state authority. The dwindling of political force has prompted religious groups to fill the space left by political parties and to emerge as an alternative social force. The shrinking political space paved the way for the emergence of religious institutions as alternative means of articulating societal interests. This has resulted in rivalries within and between religious groups, and between the latter and the state. The so-called religious fundamentalism emerged as a catchphrase of state-society relations in the post-2011 period. The state has mobilized considerable resources and used its authority to deal with the emerging challenges. However, religion has gradually emerged as a potent force in state-society relations. In Figure 1, we signify the post-1991 political dynamism in Ethiopia in sequential order. 


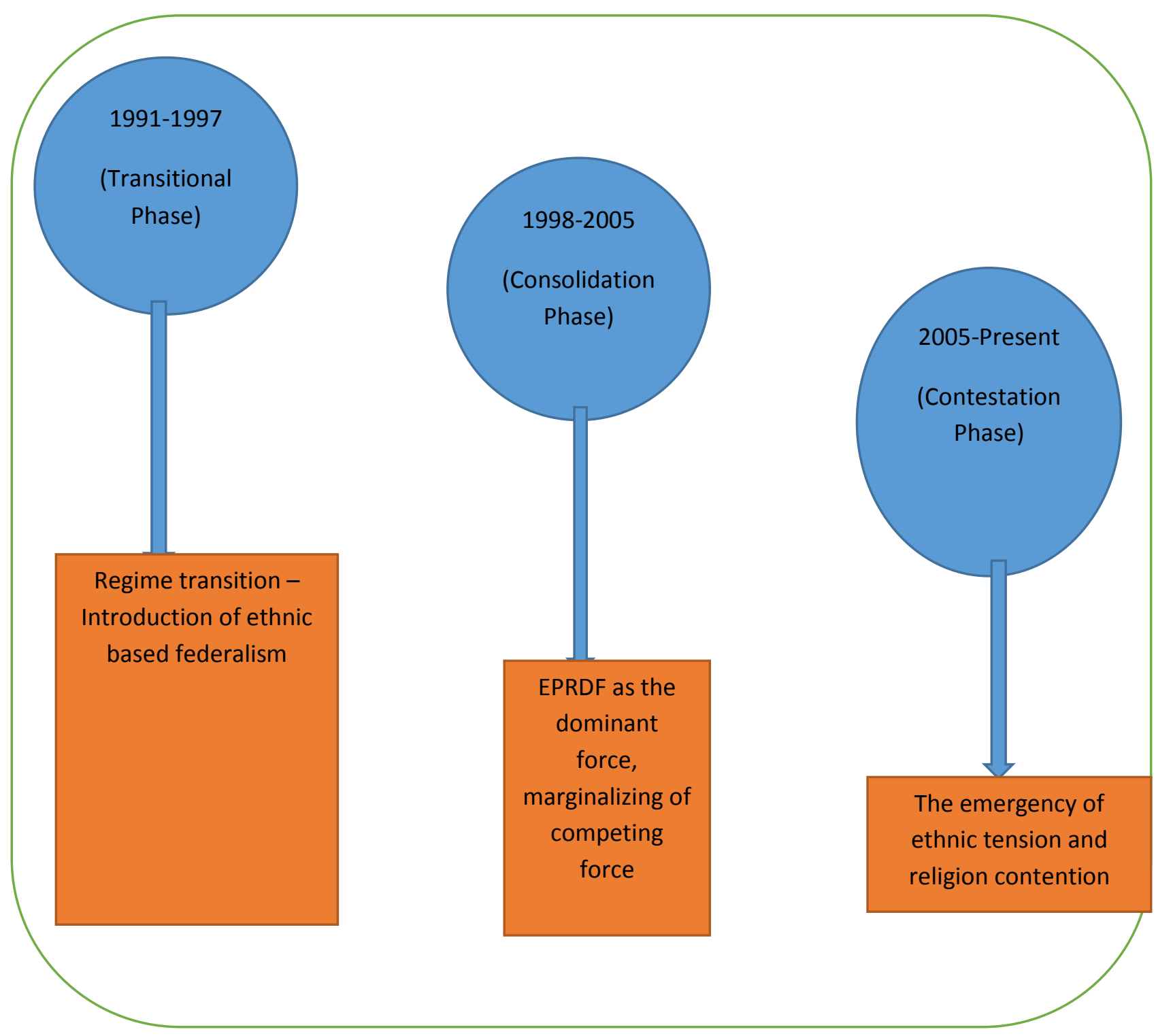

Figure 1. Post-1991 political change in sequential order;

Source: Authors Sketch, 2019

The second phase covers the years between 1998 and 2005, which signal the rise of EPRDF as single political party. EPRDF established itself as the strongest political force (Temesgen, 2015b). The fledgling political forces were either eliminated or appeased, partially as a result of their weakness and partly because of unfriendly political ground. EPRDF emerged as the strongest political force by attracting regional elites and expanding its sphere of influence. However, the 1998 Ethio-Eritrean war disrupted the consolidation efforts. In fact, EPRDF was able to become triumphant in the war effort from a military standpoint. However, it faced a major diplomatic setback that severely downgraded its legitimacy (Fessha, 2018 and Temesgen, 2015). 


\section{Ethnic Federalism and Nation Building in Current Ethiopia}

Nation-building is the most common form of a process of collective identity formation with a view to legitimizing public power within a given territory. This is an essentially indigenous process which often not only projects a meaningful future but also draws on existing traditions, institutions, and customs, redefining them as national characteristics in order to support the nation's claim to sovereignty and uniqueness. A successful nation-building process produces a cultural projection of the nation containing a certain set of assumptions, values and beliefs which can function as the legitimizing foundation of a state structure. So far, this has happened essentially in societies with substantial elements of "social modernity". Among the elements which distinguish such societies from pre-modern ones, are: an open system of stratification allowing and encouraging social mobility, the state as an impersonal form of government, the pursuit of economic growth, and a cultural system establishing collective meaning and identity for all envisaged members of society. In order to avoid misunderstanding, it is important to state the temporal and spatial contingency of the nation state, i.e. the fact that this form of political organization finds its origins in western Europe in the 18th and 19th century. (Planck, 2005)

Right after its assumption of state power in 1991, the EPRDF began its project of reconstituting the country into an ethnic federation. This process was highly influenced by Stalin's theory of nationality. Indeed, there are striking similarities between the theory and practice of Soviet and Ethiopian federalism. According to Kefale, (2014) Ethiopia adopted the Soviet practice of hierarchically categorizing its ethnic groups into "nations, national groups and peoples.' More interestingly, the 1994 Ethiopian constitution adopted Joseph Stalin's definition of the 'nation.' In this respect, Ethiopia's 'nations, nationalities and peoples' were defined by art. 20 sub article 5 of the federal constitution as:

A group of people who have or share a large measure of common culture or similar customs, mutual intelligibility of language, belief in a common or related identities, a common psychological make-up, and who inhabit an identifiable, predominantly contiguous territory.

Following the fall of the derg regime and the coming of the TPLF/EPRDF to power, one can observe that the nation-building strategy as elaborated by this front stressed the "primordial" belonging to "Nations, Nationalities and Peoples" as the basis of Ethiopians' identity. Nevertheless, Ethiopianness soon reappeared in EPRDF's discourses in the early 1990s. This multifaceted nationalism is to be explained by particular circumstances and also by the inheritance of a certain perception of the state by the TPLF leadership, related to their ambition to reshape the Ethiopian state and nation, rather than destroying it. (Bach, 2014)

Communal conflicts sparked by ethnic-based federalism have become common. While they often involve killings, displacement and property destruction, they are not directed against the federal government. Ethno-national rebellions against the EPRDF have not disappeared, however. With varying success, the ONLF, OLF, Ethiopian People's Patriotic Front (EPPF) and Tigray People's Democratic Movement (TPDM) are waging such armed struggles. Oromiya is of particular concern, since it contains 37 per cent of Ethiopia's population (roughly 27 million people). Its secession would entail disintegration of the Ethiopian state. The ONLF insurgency in Somali would not, but it has triggered a humanitarian crisis. (International Crisis Group, 2009a). Similarly Aalen, (2002) in his study indicated that in many of the units in the Ethiopian federation, 
there have been or are currently conflicts between different majority groups or between the majority and the minorities. On the other hand International Crisis Group, (2009b) stated that despite the EPRDF's authoritarianism and reluctance to accept genuine multi-party competition, political positions and parties have proliferated in recent years. This process, however, is not driven by democratization or the inclusion of opposition parties in representative institutions. Rather it is the result of a continuous polarization of national politics that has sharpened tensions between and within parties and ethnic groups since the mid-1990s. The EPRDF's ethnic federalism has not dampened con- flict, but rather increased competition among groups that vie over land and natural resources, as well as administrative boundaries and government budgets.

The new 1995 constitution recognized the "Rights of Nations, Nationalities and Peoples" (NNPs) ${ }^{1}$, supported decentralization policies from which autonomous NNPs should benefit, while the new leadership violently condemned the preceding imperial and Derg conceptions of Ethiopian nation- hood, as the following extract of EPRDF program clearly shows:

The chauvinist ruling classes adhere to the principle of "Itiopiawinnet" (Ethiopianness) which kills identity based on nationality. So they do not follow the principle of forming a nation-wide organization through a union of nation- ality-based organizations. They aspire to form a dominant multi-nation organization composed of individuals from various nationalities and ethnic organizations that have betrayed the causes of their people and bowed to these chauvinists. Secessionists and narrow nationalist organizations do not want the fulfillment of the peoples' common interests. So, they, too, do not want to form a nation-wide organization together with other nationality-based organizations ${ }^{2}$.

"Ethiopianness: a right, not an obligation" (Meles Zenawi,) ${ }^{3}$ but the idea of Ethiopianness, while strongly rejected in internal EPRDF papers, was not that radically condemned publicly, and even progressively increased again from the middle of the 1990s. In fact, it would be excessive to conclude from these irst observations that Ethiopianness purely and simply disappeared as from 1991 in EPRDF's discourses. Indeed, the Ethiopia-scale national discourse was not totally abandoned at the beginning of the 1990s, although it then ap- peared like a "second class identity", beyond the "Rights of Nations, Nationalities and Peoples". It is also worth noting the ambiguity created by the coexistence of a dual identity after: while the domestic citizenship was denied in terms of Nations, Nationalities and Peoples, it had to coexist with a remaining international Ethiopian identity (Dias, 2008, pp. 144-152) as cited in (Bach, 2014).

When journalists asked him about the coming evolution of Ethiopian citizenship, Meles Zenawi declared in 1992:

Previous approach [derg] was [...] to deny his nation, nationality identity in order to be an Ethiopian. [...] The greatest danger to unity is not accepting the fact that we can jointly retain and ascertain our Ethiopian identity while at the same time speaking our own languages, wearing our ethnic costumes and administering our own respective

\footnotetext{
${ }^{1}$ Article 39 of the Constitution of the Federal Democratic Republic of Ethiopia. The preceding Derg regime had already started to organize a federal Ethiopian state under the Stalinist theory (creation of the Institute for Ethiopian Nationalities, and the national Shengo which officially represented these nationalities according to the 1989 constitution). But in practice, the derg continued to defend a centralized, violent and unitary conception of the Ethiopian nationhood (Clapham, 1989; Dias, 2008, pp. 175-176).

${ }^{2}$ EPRDF (1993). Our Revolutionary Democratic Goals and the Next Step (1985 EC). Ethiopian Register, June 1996.

${ }^{3}$ He was the Chairperson of TPLF and 13rd prime minister of Ethiopia (1995-2012).
} 
regions [...]. If the danger is done away with, federalism will only further strengthen Ethiopia's unity and not lead to disintegration ${ }^{4}$

The Ethiopian nation-building process and TPLF/EPRDF's conception of the Ethiopian nation can also be explained by the TPLF's perception of the Ethiopian state and their pragmatic strategies during the struggle. That actually reveals the complexity of TPLF's nationalism itself. In fact, from the 1970s, TPLF's nationalism was built on the tension between historical Ethiopianness and the ideological "national oppression thesis". In this regard Baweke, (2015) indicated that, there is the need for visionary thinking outside the box of past injustices so that the antithesis for these injustices is not taken too far to the extent of derailing shared identity and shared aspirations. This indeed calls for democratic inclusive institutions for the betterment of Ethiopia's future rather than centrifugal reactions to the past.

Empires-, states- and nation-building is marked by some pivotal events refer- ring to different levels of nationalism, their (re)activations depending on particular contexts. The "liberation" struggle and the fight against imperial and derg's nationalism gave sense to a nationalism based on Nations, Nationalities and Peoples after 1991. The war against Eritrea meant resorting to broader federating symbols and pivotal events stressing the "unity" and solidarity of Ethiopian peoples. That implied the increasing use of another dimension of nationalism at state level, inherited from the imperial period-which, once again, had not disappeared since 1991. These different nationalisms do not switch places with each other, but became articulated so that the Pan-national repertories embraced those who consider themselves as Tigrayan, Oromo, Kembata and Ethiopian, or those who felt they belonged to both ethnic and Ethiopian identities.(Bach, 2014).

Ethiopia's ethnic regions generate continuing controversy regarding their long-term effects on the country's integrity (Samatar, n.d.). At one extreme, some predict that the centrifugal dynamics of Ethiopia's exclusive sub- national identities will lead to the country's disintegration, particularly since the new constitution guarantees the right to self-determination up to secession. Proponents of this thesis cite the former Soviet Union as a model of what happens when central government is weakened in previously authoritarian and ethnically divided societies. Second, supporters of the ethnically based dispensation note that the new federalism is a novel departure for Ethiopia that cannot be reversed despite teething problems. Third, other critics claim that the dominant party at the center has reneged on its democratic promise by illegally subverting free ethnic political mobilization.

The current Ethiopian government attempt to classify people by ethnic background is reminiscent of practices which used to exist in the former Soviet Union and in South Africa. It looks totally different to a political process one of whose objective is to promote a common Ethiopian national identity. It also seems unfitting in a country in which substantial portions of the population are of diverse ethnic background or unsure of which ethnic group they belong to or wish to identify with.

\footnotetext{
4 "President Meles Zenawi replies to questions posed by journalists", The Ethiopian Herald, 23, 24, and 25 September 1992. 22.
} 


\section{Conclusion}

It also briefly states how ethnic federalism is linked with nation building and impact development, including the implications which have been reflected from the 1995 Ethiopian Constitution in bringing national integration for collective aspirations and common economic and political destiny. The challenges encountered in the course of the Ethiopia federation in the course of assuring the propriety of acts of political units in the course of selfadministration and the corresponding sense of shared destiny and cooperation among different national communities are also issues of concern.

There are obviously two arguments that is pro and against ethnic federalism. It is not the principle of ethnic-based regionalization per se that has proved problematic. Rather it is that Ethiopia's ethnic dispersion is seldom homogenous. More gravely, the idea of unconditional "self-determination" encour-ages local officials to establish an administrative unit on an exclusive basis in order to access state resources. Consequently, ethnic federalism has sharpened differences among groups since 1991, and ethno-nationalist grievances with the nation-state, which the TPLF set out to end, remain. Displeasure with the central government in broad segments of the Oromo and Somali population fuels the armed struggles of the OLF and ONLF respectively (International Crisis Group, 2009a). For nationalists, the policy is a deliberate ploy to under- mine national identity, pride and self-esteem flowing from the exceptional history and continuity of the Abyssinian empire and Ethiopian state. They see the constitutional granting of self-determination to ethnic groups as a deliberate step backward from the nation- building process.

Article 39 of the FDRE constitution of Ethiopia gives self-determination including up to secession, but secession would have not been devised as a means of solving conflicts rather it should be just to daunt such secessionist resentment in the first place and when this is not successful, allow for the likelihood of secession in accordance with terms of democracy, justice and rule of law. The secession section of Ethiopia quiet remains challenged and constitutionally unjustified. This needs a revisit of the Constitutional arrangement through applied politics or legal repeal. The leadership since 1991 institutionalized ethnic federalism as a matter of ideological orientation and political necessity and as a way of resolving conflict between ethnonationalism and the state. The fact that most ethnic groups appear willing to live within the framework of the federal system is, in part, an achievement of ethnic federalism. Thus far, ethnic federalism has undercut the drive for secession by largely removing manifest aspects of ethnic oppression (e.g., language use) that would have served as a rallying cause for ethnonationalist organizations. Through its cultural pluralist and political autonomy policies, ethnic federalism has contributed to state maintenance.

There are competing claims, for and against ethnic federalism. Proponents of ethnic regionalization acclaim the recognition of group rights, seeing creation of ethnic- based administrative entities as the only meaningful approach for defusing ethnic discontents. According to this view - actively propagated by the government - Ethiopia's ethnic and minority groups have suffered centuries of domination by a central state that forced Am-haric language and culture upon them. Granting "nation- alities" their cultural, ethnic, and political aspirations is necessary to redress historic injustices and decolonise the country. Equality among citizens cannot be realised by forcing a pre-defined national identity upon them but only by recognising existing differences and allowing the articulation of their interests at the central level. 
The international community has ignored or downplayed the problems. Some donors consider food security more important than democracy in Ethiopia. In view of the mounting ethnic awareness and political tensions created by the regionalisation policy, however, external actors would be well advised to take the governance problems more seriously and adopt a more principled position towards the Ethiopian government.

\section{Acronyms}

FDRE-Federal Democratic Republic of Ethiopia

EPRDF- Ethiopian People Revolutionary Democratic Front

TPLF- Tigray Peoples' Liberation Front

\section{References}

Aalen, L. (2002). Ethnic federalism in a dominant party state: The Ethiopian experience 1991-2000. In Report - Chr. Michelsen Institute.

Abbink, J. (2009). The Ethiopian Second Republic and the Fragile "Social Contract." Africa Spectrum, $44(2), 3-28$.

Abebe, S. G. (2012). The dilemma of adopting ethnic federal system in Africa in light of the perspectives from Ethiopian experience. Journal of African Studies and Development, 4(7), 168-175. https://doi.org/10.5897/JASD12.021.

Bach, J.-N. (2014). EPRDF's Nation-Building: Tinkering with convictions and pragmatism1 A EPRDF e a construção da nação: Ajustes nas convicções e pragmatismo. Cadernos de Estudos Africanos, (27). https://doi.org/10.4000/cea.1501.

Baweke, E. C. (2015). Ethnic Federalism and Nation Building In Development: Addis Abeba.

Bekele, Y. W., Kjosavik, D. J., \& Shanmugaratnam, N. (2016). State-Society Relations in Ethiopia: A Political- Economy Perspective of the Post-1991 Order. https://doi.org/10 .3390/socsci5030048.

Beken, C. Van Der. (2007). ETHIOPIA: Constitutional Protection Of Ethnic Minorities At The Regional. $20(1), 105-151$.

Fessha, Y. T. and Van der Beken, C. (2013). Ethnic federalism and internal minorities: the legal protection of internal minorities in Ethiopia. African Journal of International and Comparative Law, Comparative Law, 21(1), 32-49. https://doi.org/http://dx.doi.org/ 10.3366/ajicl.2013.0051.

Fessha, Y. (2018). The Original Sin of Ethiopian Federalism. (January). https://doi.org/10.1080/ 17449057.2016.1254410.

Gizachew, G. W. (2019). Minority and federalism: an assessment of the right to political participation of " non-indigenous' peoples in Benishangul-Gumuz Regional State, Ethiopia Gifayehu Wondie Gizachew. Int. J. Human Rights and Constitutional Studies, 6(3), 192-213.

Habtu, A. (2003). Ethnic Federalism in Ethiopia: Background, Present Conditions and Future Prospects. 
International Crisis Group. (2009a). Ethiopia: Ethnic Federalism And Its Discontents. Africa Report, (September).

International Crisis Group. (2009b). Ethiopia: Ethnic Federalism and Its Discontents. (September), 1-41. Retrieved from http://scholar.google.com/scholar?hl=en\&btnG=Search\&q=intitle:ETHIOPIA+ :+ETHNIC+FEDERALISM+AND+ITS+DISCONTENTS\#1.

Kefale, A. (2014). Ethiopia' s Ethnic Federalism : History and Ideology. Federalism and Ethnic Conflict in Ethiopia A Comparative Regional Study, 54-79.

Mengistu, M. M. (2015). Ethnic Federalism: A Means for Managing or a Triggering Factor for Ethnic Conflicts in Ethiopia. Social Science, 4(4), 94-105. https://doi.org/10.11648/j.ss. 20150404.15.

Planck, M. (2005). Constitutional Politics in Post-Conflict Situations : Conceptual Clarifications and an Appraisal of Different Approaches. 9, 579-613.

Samatar, A. I. (n.d.). and Regional Autonomy: The Somali Test 1. 44-76.

Temesgen, S. M. (2015a). Weaknesses of Ethnic Federalism in Ethiopia. International Journal of Humanities and Social Science Invention, 4(11), 49-54. https://doi.org/10.1093/publius/pji016.

Temesgen, S. M. (2015b). Weaknesses of Ethnic Federalism in Ethiopia. International Journal of Humanities and Social Science Invention, 4(11), 49-54.

\section{Copyrights}

Copyright for this article is retained by the author(s), with first publication rights granted to the journal.

This is an open-access article distributed under the terms and conditions of the Creative Commons Attribution license (http://creativecommons.org/licenses/by/4.0/). 